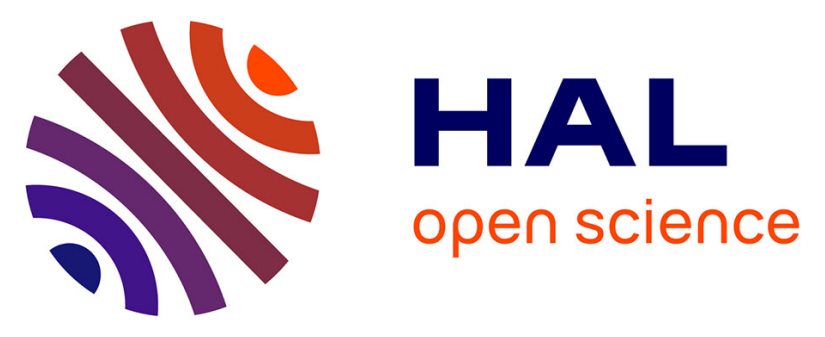

\title{
The check and the guardianship: A comparison of surveillance at an airport and a housing-estate area in the Paris outskirts
}

Fabien Jobard, Dominique Linhardt

\section{- To cite this version:}

Fabien Jobard, Dominique Linhardt. The check and the guardianship: A comparison of surveillance at an airport and a housing-estate area in the Paris outskirts. Mathieu Deflem and Jeffrey T. Ulmer. Surveillance and Governance: Crime Control and Beyond, Emerald, pp.75-100, 2008, Sociology of Crime Law and Deviance, Volume 10, 978-0-7623-1416-4 (print) / 978-1-84950-558-1 (online). 10.1016/S1521-6136(07)00204-7 . hal-00559794

\section{HAL Id: hal-00559794 \\ https://hal.science/hal-00559794}

Submitted on 18 Nov 2013

HAL is a multi-disciplinary open access archive for the deposit and dissemination of scientific research documents, whether they are published or not. The documents may come from teaching and research institutions in France or abroad, or from public or private research centers.
L'archive ouverte pluridisciplinaire HAL, est destinée au dépôt et à la diffusion de documents scientifiques de niveau recherche, publiés ou non, émanant des établissements d'enseignement et de recherche français ou étrangers, des laboratoires publics ou privés. 
15 Fabien Jobard and Dominique Linhardt

\author{
ABSTRACT
}

This chapter approaches the question of government and surveillance through a comparison between the control practices observable in two types of places. First, we focus on international airports, specifically the French international airport of Orly. Airports are maximum security zones where persons perceived as having no legitimate business are expelled and where suspicious objects are destroyed. The second kind of places are the ones labeled as "no-go areas", violent pockets within urban space. Social housing projects located in the bleak suburbs of French cities are such danger zones. Both kinds of places - airports and no-go areas have very different time and space features: people briefly pass through anonymous airports where relationships are kept at an impersonal minimum, whereas the population of a housing estate area is made of "permanent transients" pinned down by a shared fate of which there seems no escape.

Surveillance and Governance 
3 The term surveillance raises a lexical difficulty which complicates its theoretical implications as well as its empirical specification. Narrowly

5 understood, it refers to the set of processes and measures through which the State is informed of the activities of a person or of a group of persons while

7 avoiding repressive action, either because no offence has actually been identified or because the government prefers, for one reason or another, to

9 be discrete (Fijnaut \& Marx, 1995; Sharpe, 2000). Yet, Michel Foucault's seminal work Surveiller et punir was translated into English under the title

11 Discipline and Punish (Foucault, 1977). In this latter disciplinary understanding, the notion of surveillance has to do with a much broader

13 field (Deleuze, 1988). It ceases to be a mere policing tool among many others in the State's policing arsenal, and instead becomes a regime of

15 "governmentality" combining and articulating different technologies, strategies, and governmental rationalities (Miller \& Rose, 1992). Accord- AU:2

17 ingly, surveillance becomes a notion to describe a specific way through which human behavior is apprehended, and hence ensure predictability,

19 calculability, and "governability" (Gandy, 1993; Lyon, 1994; Wood, 2003). Here, of course, we find ourselves following a path opened by Foucault

21 (1988) and followed by many others since (for instance Rose, 2000).

However, whether one understands the notion of surveillance in its narrow

23 sense, as a mere set of disparate means within a governmental apparatus, or, on the contrary, as the basis for the constitution of a governmentality regime

25 which relies on spotting, identification, and control, using number of techniques, devices, and processes, in both cases, the risk is that surveillance

27 becomes an "all-terrain" notion which has less and less to do with the ground realities of its implementation. As David Garland (1997) strongly underlines,

29 the notion of surveillance could then lead directly to a variant of reductionism: applicable to too many situations, it would, at the same time, suppress the

31 empirical specificities of each one. This inclination is all the more detrimental that, in polishing the ruggedness of reality, it contributes to neglecting the

33 uniqueness of the organizational methods and the institutional layouts, the various types of intervention, and of the stocks of knowledge precisely meant to

35 define the "surveillance society." Yet, if there were one systematic observation to report, it would be the multiplicity and variability of the devices of

37 surveillance. Each of these devices adapts to specific constellations, which have characteristic social, spatial, and temporal indicators, and are defined by the

39 nature of the threats and the risks that operate inside of them. The differences from one constellation to another are what deserve particular attention. 
1 Our approach answers the need felt for a return to the scrutiny of the actual modalities in place in the practice of surveillance. To this effect, we

3 chose to anchor the description in space, reminding the reader that Michel Foucault's analyses of surveillance were above all analyses of the

5 spatialization of power (enclosed areas in the treatment of insanity, confined areas in the containment of contagious diseases, areas of panoptical

7 centrality in the disciplinary process, territorialized space in the security process, etc.). ${ }^{1}$ We have deliberately stressed the contrast between two

9 unique sites, both of which underwent an in-depth empirical study. Both are located in the southern Paris agglomeration, they only stand a few miles

11 from each other. In both cases, security, control, and surveillance are highstake and greatly sensitive issues. Yet, everything seems to separate them:

13 when not a blatant antinomy, the surveillance practices at Orly airport on the one side and in the Bas-Moulin housing project of Dammarie-les-Lys on

15 the other diverge entirely, in many respects. As we will establish, in the first case, surveillance takes the form of a checking, in contrast to the second,

17 where it takes the form of guardianship.

An airport, a housing project: are the intrinsic differences between the

19 two not so great that any comparison would only resemble a far-fetched artifact? We find such resistance unnecessary: if indeed surveillance and

21 governance are broad concepts, then they must be able to welcome differences, as extreme as they may seem. But more importantly from an

23 empirical standpoint, one cannot overlook the fact that both sites face the same "problematic of government" (Miller \& Rose, 1992): that of security.

25 A technical problem for experts to solve on one level, the question of security nonetheless becomes a public matter when its treatment or

27 non-treatment affects public opinion, and is likely to enter a controversy where lack of security is then seen as the problem and surveillance as its

29 solution.

\section{VARIABLES USED IN THE DESCRIPTION} AND THE ANALYSIS

Both the studies of the Orly airport and of the housing project in

37 Dammarie-les-Lys were undertaken using the classical tools of the qualitative method (i.e., empirical observations and interviews). In order

39 to facilitate comparative analysis, however, we entered the collected data into one same analytical grid, in which a number of variables are tertio 
1 comparationis - their value thus varies according to where they were collected. Table 1 gives an idea of what type of variables we are referring to.

3 The variables we identified are of two different sorts. The first is purely descriptive: the variables have to do with matters of fact noted from our

5 field observations, and do not require specific interpretation. The first variable (A) corresponds to the institutional arrangement within which the

7 actors of surveillance find themselves; accordingly, it is a description of the various types of cooperation, lines of conflict, distribution of tasks,

9 and share of responsibility in the site under study. The second variable (B) characterizes how the surveillance apparatus defines the targets of

11 surveillance. The third variable (C) allows us to specify the type of interaction existing between the surveillance agents and the surveillance

13 targets, the main point being to identify whether interactions are unique, or whether, on the contrary, there is a principle of reiteration of

15 interaction. The fourth variable (D) allows us to classify surveillance apparatuses according to whether or not they require records and to how

17 collected records are reinvested in the surveillance practices. The fifth variable (E) allows for a better apprehension of the various sources of

19 legitimacy with regard to the authorization and supervision of the interventions in the different spaces, according to the constraints they

21 themselves face.

The second type of variable is analytical. While these may be inferred

23 from the previous sort, they nonetheless require a higher qualification process than does mere observation. The first of these analytical variables

25 (F) seeks to compare the effects of surveillance practices at each site; it distributes the effects on a continuum extending from the "objectification"

27 of the individual targets to their "subjectification." The second analytical variable $(\mathrm{G})$ has to do with the modalities of "we"-formations. For, the

29 deployment of an apparatus affects not only individual subjectivities, but also creates collective subjectivities, or even communities, whose

31 relationship with surveillance services is a relevant matter. The last analytical variable $(\mathrm{H})$, based on a synthesis of the previous variables,

33 seeks to precisely characterize the nature of the intervention at each site. In what follows, and based on the aforementioned variables, we would

35 like to go beyond merely describing the case studies by showing evidence of two contrasting models of surveillance and of governance of behaviors:

37 the check model found on the grounds of the airport, and the guardianship model observable on the grounds of the suburban housing 39 project. $^{2}$ 
Table 1. Categories of Comparison.

3

Variables

Descriptive Variables

Relevant Questions

5

(A) Institutional arrangement

7

9

11

(B) Targets of surveillance

13

(C) Type of interaction

15

17

19

21

(E)
Absence or presence of
records

Sources of legitimacy

Analytical Variables

Relevant Questions

What is the institutional arrangement between the various security agencies involved in the apparatus? What is the impact of the arrangement on the spatial organization and the responsibility distribution?

How are the surveillance targets defined? How does this definition affect the surveillance apparatus in itself?

What is the nature of the relationship between the surveillance actors and the individuals under surveillance? Are their interactions unique, or reiterated?

Does the surveillance apparatus rest on recording devices and the production of a type memory? Or is the amnesia of the apparatus intentional?

What is the normative justification for the surveillance apparatus? How are the presence and operations of the surveillance actors justified?
27

29

Type of intervention its targets

(G) targets
Effects of surveillance on the individual status of

Effects of surveillance on the collective status of its

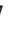

What is the nature of the individual identity produced by surveillance? Does surveillance create subjects, or is it searching for objectification?

Does surveillance produce a collective identity of individuals under surveillance? How does it infer a sense of collective identity? What are the types of "we" that emerge from it?

Everything taken into account, how can the type of surveillance actors intervention be qualified? What does the relationship between surveillance and space and temporality imply? 
3 Terrorism has a strong relationship with the massive streams of mobility which characterize our societies (Urry, 2000) (E). Indeed, the terrorist

5 enterprise is doubly dependent on the socio-technical systems, which are vital to them. First, mobility infrastructures give terrorists the perfect

7 conditions to achieve their goals. Answering a constant need to conceal themselves, the anonymous streams of movement appear as a perfect

9 hideout for terrorists (Linhardt, 2006). From there, they can attack the infrastructures of mobility themselves and the people who are inside them,

11 since, while offering terrorists a form of protection, the targets of the terrorist enterprise only become more vulnerable. Air transportation was

13 faced with this problem very early on. From this standpoint, the September 11th attacks were only the temporary end of a long-lasting relationship

15 between terrorism and civil aviation (Crenshaw, 1988; Merari, 1998; Lyon, 2003). Throughout the relationship, specific prevention systems have been

17 set up. These systems have quite obviously evolved since the end of the 1960s, in step with the evolution of the threat itself. ${ }^{3}$

19 Paris Orly airport has faced terrorist threats more than once. It does not, however, show any particular characteristic distinguishing it from other

21 international airports on this level. This is all the more true in light of the fact that air transportation security is a matter for international institutions,

23 which ensure that procedures are normalized beyond national borders and local specificities (Wallis, 1998). Thus, while the site under observation is

25 Orly, the point is not to underline any form of specificity at Orly. Quite the contrary: given the constant normalization of the place, the study shows

27 how Orly's security apparatus more or less fits the framework found in other airports.

33 In order to understand the mechanisms of airport terrorism prevention, it is appropriate to start from the terrorist enterprise. One way to characterize

35 it is to recognize it as a game with "normal appearance" (Goffman, 1971, p. 256). Terrorists act from an ambush which is not a physical, but, rather, a

37 "social ambush" (Walzer, 1977, p. 176): they blend into the normality of daily coexistence by borrowing a commonplace, negligible or plain physical

39 appearance: nothing looks more like a lambda traveler than a terrorist checking in, or a hijacker going through security. ${ }^{4}$ This specificity of 
1 terrorists to act in such a way so as to follow through with their goal while concealing it under normality implies that those who seek to stop them must

3 know how to see behind what a person or object is putting on display. Indeed, the real capacity to strike back is measured by the ability to identify

5 and seize terrorists despite their concealment strategies. In the undifferentiated world of streams of travelers, control means a re-discrimination, a

7 sorting between ordinary and ill-intentioned individuals with the implementation of suspicion (B) (Adey, 2003).

9 The airport example clearly shows that the practice of suspicion is less arbitrary than one might consider it when associating it with a conception of

11 the notion which rests mainly on intuition. Economy of suspicion at the Orly airport rests exclusively on an advanced codification, formalization,

13 and division of labor. The imperative of suspicion is delegated to an apparatus whose quality will depend on the specific lineup of the persons

15 and the objects within the apparatus determined by pre-defined scripts (Akrich, 1992). Hence, suspicion takes form from routine procedures $(\mathrm{H})$.

17 This explains the importance of the organizational aspects of airport security.

\section{Spatial Organization: Zoning}

21 This organization rests above all on a penetration of the area. The airport space undergoes a thorough process of subdivision before the streams of

23 people crossing the zones are actively controlled. Airport security is conceived on a model of concentric circles surrounding the aircraft: the

25 closer one gets, the more limited the access of persons (passengers, employees) and objects (luggage, shipments), which is only authorized after

27 strict inspection, becomes. Accordingly, the space is divided in to various zones of different status; each border between two contiguous zones of

29 different status is either rendered completely hermetic by physical barriers, or offers access opportunities (E). ${ }^{5}$

\section{Zoning and Distribution of Responsibilities}

33 The zoning goes hand in hand with a strict distribution of responsibilities. The Prefect of the department holds ultimate authority in terms of the

35 security of the airport. His main roles are the elaboration, implementation, and monitoring of the "Airport security plan", and the management of

37 crises. More specifically, he decides which zones are open to the public and which are restricted, what the conditions for traffic and parking of persons

39 and vehicles within the restricted zones are, and what the set up ensuring the security of vehicles, equipment, and goods in these zones should be. 
1 In addition, he has ultimate authority over airport coordination bodies such as the Local Security Committee and the Operational Security Committee.

3 As for on-the-ground operations, every zone type is attached to a specific institution. Hence, the national police force is responsible for the public

5 zone, the functional sectors within the airport, and the security sectors for passengers. The air transportation Gendarmerie is responsible for the

7 aircraft security sectors and the functional sectors outside the airport, and for luggage and shipment security on national flights. As for the security

9 sectors for luggage and shipments on international flights, they are taken care of by the customs service. It is important to note that the actual security

11 check operations are not carried out by police officers or customs agents: they are delegated to private companies whose agents are paid for by the

13 airlines and the airport operator. These agents nonetheless answer to a regulatory authority, to which they must immediately turn if they suspect

15 anything is wrong (A).

\section{The Rationale of the Check}

The cross-over areas between zones have a particular denotation: they act as

19 cognitive tide gates where vigilance and suspicion are constantly practiced in order to determine whether a person or object may pass or whether their

21 access should be denied. This creates a dilemma: when can one effectively pass judgment as to whether a passenger or an object is "clean" enough?

23 The social ambush strategy of terrorists makes it necessary to take small details into account, as potential clues. The clues agents will be looking for

25 depend on existing available knowledge concerning the terrorist enterprise: a certain number of features are selected, and serve as a basis for control

27 operations. Terrorists need weapons, for instance. These weapons are made of specific, easily identifiable materials. Weapons which can be used to

29 hijack an airplane and could be used in the pilot's cabin, for example, are usually made of metal. Consequently, the clue the agents will be looking for

31 during hand luggage checks is the presence of metallic objects. As for checked luggage, they will look for what is known as the "pyrotechnic

33 chain", that is, the simultaneous presence of three elements: an explosive, a detonator, and a power source.

35 In order to detect the presence of such elements, agents use sophisticated equipment whose "cognitive artifacts" (Norman, 1991) help see beyond

37 what can be seen with a naked eye. Despite such technical sophistication, however, what vigilance ultimately requires is a sense of normality. This

39 sense of normality is directly integrated into the devices and can be detected independently from the operator, but when the equipment informs an agent 
1 of some form of abnormality, he or she will have to assess it according to their own sense of normality. It is rare for an agent to instantly recognize the

3 nature of the abnormality, or what it is due to. His or her degree of certainty will affect his or her interpretation. This is the "investigation" stage.

5 The depth at which the investigation is be pursued will depend on the "importance" the interpreted detail may have, and, more particularly,

7 on the assessment of the risk taken in closing a case when the degree of certainty is still low (Schütz, 1971, p. 77). On the other hand, one must avoid

9 falling into an attitude of constant suspicion and paranoia. Thus, there must be predetermined criteria which allows agents to assess the value of the clue

$11(\mathrm{H})$. This check rationale implies putting every human being in circulation in the airport through a short test, whose purpose is to verify the absence

13 of pre-defined clues. Once this absence is confirmed, the test is over (Pinch, 2003).

\section{Controlling Customers and Citizens of Law}

This test-oriented filtering technology can be understood as a form of

21 political semiology (Linhardt, 2001). Here, actors assess in situ whether or not they are facing danger through the interpretation of small and

23 predetermined details. This semiology, which allows for an appropriate economy of suspicion, is seen as beneficial by all security actors: indeed, the

25 ability to differentiate between dangerous and non-dangerous situations is considered a pledge of efficiency. This does not prevent the security

27 apparatus from being strongly criticized. In fact, two types of criticism are quite common. The first points at the flaws in the apparatus and considers

29 the airport to be completely inefficient in preventing well-prepared terrorists from acting even though it may, at best, succeed in stopping "amateurs."

31 This criticism obviously plays a crucial role in the constant modification of the apparatus. However, we will focus on the second criticism, which points

33 to risks of violation of the rights and freedoms of those individuals who undergo security checks. Potential violations, the argument holds, are: the

35 violation of the freedom of movement, the invasion of privacy, and the violation of the protection against arbitrary treatment by authorities (E).

37 The evocation of such rights and liberties is made particularly relevant by the fact that the subjects of the law also happen to be customers (B). ${ }^{6}$ In all

39 three cases, nonetheless, we will see that it is possible to demonstrate that the airport's security apparatus can coexist with individual rights and freedoms. 
1 The Risk of Violation of the Right to Move Freely Within a Given Territory With regard to mobility rights, the issue was addressed by the introduction

3 of the security apparatus in specific areas of the airport designed to fill the requirements of an efficient air transport system. Zoning came as an

5 additional tool for distinguishing various sectors from each other according to their role within the system. Such differentiations according to

7 functionality show that security is an intrinsic part of the air transport system: the security apparatus is a just another element of the entire process.

9 Rather than being permanently open or closed, the doors remain "halfopen." The apparatus allows the airport access zones to act like a binary

11 switch: if the "cleanness" of the passenger is proven, he or she can go through. If not, the doors remain shut (E).

13

\section{The Risk of Invasion of Privacy}

15 The various forms of security check also limit the risk of an invasion of privacy. Metal detectors only permit agents to see if passengers are carrying

17 metallic objects; besides, the images of the contents of luggage provided by $\mathrm{X}$-rays have more to do with expressionist painting than photography. This

19 indicates that the goal here is not to show everything, but rather to show as little as possible while ensuring that the important elements become visible.

21 It corresponds quite precisely to what Bruno Latour and Emilie Hermant call the "oligoptic" (Latour \& Hermant, 1998, pp. 76-80), as opposed to

23 Foucault's "panoptic": to see very little, but to see very clearly. Foucault's "microphysics" (Foucault, 1975) do indeed appear rather gigantic, here, in

25 comparison to a kind of "nanophysics" of vanishing clues: the beep of a metal detector, colors on a screen, the glance in a bag. But at the same time as

27 the field of vision diminishes, the precision of what can be seen increases (F).

29 The Risk of Violation of the Protection Against Arbitrary Treatment by Authorities

31 It takes a triple operation to calm the feelings of unfair treatment created by misplaced suspicion. The first operation consists in shifting the attention

33 from the terrorist to the "unclean" passerby, for security devices do not, indeed, detect terrorists per se, but only "unclean" individuals or objects.

35 The second operation consists in disconnecting suspicion from subjectivity by making the practice of suspicion "mechanical": vigilance is made a

37 "machine-like action" (Collins, 1992). The point is to make the process uniform, and to ensure the iteration of identical actions at any given point in

39 the mechanism (F). A tempting analogy is that of a "taylorization" of suspicion, where vigilance is no longer individual or subjective, but 
1 collective and objective. The regulation and normalization of the security apparatus is largely comparable to the technical formatting of vigilance by

3 the preliminary definition of "behavioral coordinates of action" to which the components of the apparatus must react regardless of their qualities or

5 flaws, psychological states, moods, mental representations, or ideologies. This taylorization is, in fact, the guarantee of impartiality: just as the

7 terrorist is "objectified", so is suspicion, in that it is under coded restraints which go beyond the agent $(F)$. Finally, the third operation consists in

9 refusing to keep any database or record of the security checks, or to link them to a "center of calculation" (Latour, 1987, p. 235) (D). Each security

11 check operation is closed on itself, and restricted to a certain location; it cannot be moved, and can rarely be expanded (C). For instance, when a

13 passenger leaves a boarding area he has been authorized to access and then wishes to return, he or she will have to go through the security check process

15 again, since the apparatus will not have kept any records of the previous security check (D).

17 The extent of protection guaranteed by the absence of records and databases can be measured by the recent debates concerning the

19 introduction of measures requiring centralized databases. Following the September 11th attacks, the U.S. Transportation Security Administration

21 (TSA) announced its intention to introduce a new passenger profiling system. Amongst other things, the system would have required every

23 passenger to reveal their name, date of birth, address, and phone number. Security guards would have had to check the information along with other

25 available data before giving a "risk potential" score to each passenger (Adey, 2003; Lyon, 2003; Singel, 2003). The plan was strongly criticized, and

27 raised concern that it would permit for passenger surveillance to become an excuse for the scrutiny of private information such as financial transactions,

29 and the use of biometric databases (D).

It is possible that, in the long term, airport terrorism prevention converges 31 with the guardianship model developed below. Up to the present, however, developments at Orly airport have remained experimental. The general

33 framework is still one of repetition of standardized methods to reducing suspicion through binary-type tests, which everyone needs to undergo so

35 that agents may detect the absence or presence of previously defined clues. Given the rare occasions on which the airport will actually be confronted

37 with terrorists, it is tempting to question how the efficiency of the whole apparatus can be measured. On the other hand, the airport is constantly

39 confronted with millions of passengers passing through it. In a sense, then, the apparatus can be only looked at in the context of preparation for defense 
1 against an absent enemy. It must also be understood as a form of alliance between the checking agents and the checked individuals: "we together must

3 protect ourselves against them." The checking agents and checked individuals form a micro-system where, in order for the political technology

5 to be considered part of the democratic machine (Linhardt, 2000), the former must show respect to the latter. In light of recent developments,

7 it is appropriate to hope that Orly airport does not come to resemble Dammarie-les-Lys in the near future. A heteropia today (Foucault, 2001;

9 Salter, 2007), Orly would then inevitably become a dystopia.

\section{DAMMARIE-LES-LYS: THE GUARDIANSHIP MODEL}

Second policing area: Dammarie-les-Lys and the Bas-Moulin housing

15 project. The type of policing practiced there is in direct opposition to the type of policing exercised in Orly. Here, too, there is a specific security

17 apparatus, a characteristic relationship between surveillance agents and individuals under surveillance, between those who hold a monopoly on

19 legitimate violence and the subjects to the law. The relationships and apparatus do not, however, rest on the success of a test system, but on a

21 form of guardianship.

Dammarie-les-Lys was chosen because of a local historical specificity.

23 In the summer of 2002, an unexpected event took place: there was a political mobilization in the housing estate. This mobilization had developed in

25 reaction to two deaths, which had occurred during police intervention, one on May 21st, the other on May 23rd. The event was indeed unexpected,

27 since it was one of conventional kind: no disorders, riots, destructions, street-battles, but demonstrations, public claims made to the local

29 government, press coverage, calls to political organizations, etc. It marked a departure from the contentious repertoires usually resorted to by youths

31 from French deprived urban areas (known as "banlieues") in similar cases, such as "coordinated destructions" and "scattered attacks" (Tilly, 2003,

33 p. 15). Typically, in December 1997, when a 17-year-old youth was shot and killed by a police officer, Dammarie's housing project underwent three

35 nights of violent attacks comparable to those which took place on the entire French territory in October and November 2005 (Roy, 2005; Jobard, 2007).

37 The 2002 rallying broke the cycle of the "routinization of rioting" (Campbell, 1983) noted in Dammarie-les-Lys, and other similar places.

39 Two specific features of the political mobilization are addressed below. ${ }^{8}$ First, the interlacing of routine and exception $(\mathrm{H})$, a feature which is 
1 characteristic to the place and will be illustrated by an intervention of the new repressive unit, the "GIR" (A); second, the priority given to two

3 overlaying approaches: the familiarity (B) and longstanding nature (C) of the interpersonal relationships between the surveillance agents and individuals under surveillance.

\section{Routinization of Exception}

End of May 2002: after a presidential race dominated by crime and 11 disorders issues, President Chirac is reelected with almost $90 \%$ of the votes in the second run against Jean Marie Le Pen, the far-right candidate. A new

13 Interior Minister, Nicolas Sarkozy, is appointed, and immediately sets up a new squad, the GIR (Groupes d'intervention et de recherche). These groups

15 are the product of a superposition of all the existing policing, administrative, and judiciary services (A): Gendarmerie (i.e., military police force), national

17 police (i.e., local civil police force), customs, public prosecutor, fiscal administration, etc. Investigating and administrative agents show up under

19 the protection of a number of forces similar to the paramilitary police units described by Kraska and Kappeller (1997). Their conformity with the

21 general principles of law is fragile, for their authority emanates from elected officials and prefects, when judiciary matters are independent from the

23 government. This is why the use of GIR is exceptional in itself $(\mathrm{H})$, which consist in "crackdown" missions on drugs, gun trade, prostitution networks, 25 or illegal immigration operations.

The housing project of Dammarie-les-Lys, and more specifically the Bas-

27 Moulin block, where the family of the second youth killed in the May 2002 tragedies lives, was surrounded by a GIR on the morning of June 27 th, at

296.00 a.m. But the GIR, who entered the local youth center, destroyed it and finally managed to get the court bailiffs to shut it down and seal its doors;

31 the GIR, who proceeded to identity checks on every inhabitant of the building, did not come alone. Indeed, they came accompanied by riot police

33 forces and marksmen positioned on the roof of the high-rise facing the BasMoulin building (A).

35 On July 10th, Interior Minister Sarkozy shared his views on his own security policies implemented in skid-row areas:

Police forces must regain control in abandoned territories. Let's take an example. There is a housing project, in Dammarie-les-Lys, in which neither police nor gendarmerie couldn't set foot any more. For years, people lived in fear there. A few days ago, the GIR went there. It was disappointing on a penal level, but for the people who live there, and 
the vast majority of them are honest citizens whose only claim is their right to lead a peaceful daily life, well, they suddenly thought 'we're not abandoned anymore.

Two political rationalities were put forward ${ }^{9}$ : the first was the consecration of the legitimacy of the State, of the power of public institutions, and of their continuous territorial coverage. The second was the preservation of public order (E). The GIR intervention rests on an economy of fear and of rights. The target areas thus became a platform for the public display of State sovereignty. State's administration spread out in three different ways: a deployment of deterring physical and military forces, identity checks, and the eviction and rampage of the local youth center.

\section{The Show of Power}

There is no doubt that the goal of the intervention was to physically close the protest area off from the rest of the city. The number of police officers (around 250), and their lay out (two officers every $10 \mathrm{~m}$, deployment of forces on the roofs, a continuous line of police cars driving around the building, revealing policemen armed with flash-balls and ensuring that the

19 Bas-Moulin was entirely surrounded) allow for no ambiguity concerning their geographic target.

21 The physical separation between the flashpoint (Waddington, Jones, \& Critcher, 1989) and the rest of the city places the presence of the police

23 forces within a purely military semiology, where the display of weapons appears as a deterring sign of the power of the State (E), as opposed to the

25 case of Orly, where police presence can be understood as part of a political semiology.

\section{Identity Checks on Inhabitants}

29 From 6:30 a.m. to 8:00 a.m., every Bas-Moulin inhabitant had to submit to identity checks, under so-called "administrative" (i.e., routine, not judiciary)

31 procedures provided by articles 78-2 and 78-2-2 of the Criminal proceedings code (CPP), allowing the authorities to check the identity of "any person,

33 regardless of his or her behavior ... where the authorities have knowledge of repeated offenses, but have not identified their perpetrators." The whole

35 operation led to the arrest of two illegal migrants ("The operation was disappointing on a penal level", M. Sarkozy then said).

37 The intervention sheds light on another specificity of the type of policing in the area. Contrary to Orly, where the administration is based on the

39 presumption of "cleanness" paired with a technical apparatus allowing for the emergence of suspicion if necessary, here, individuals are always a priori 
1 suspected of disrupting public order. Accordingly, the administration demands proof that a person is complying with his or her legal status

3 (through the identity check): the use of this method limits the individual's identity to the one the policeman is verifying, leading to a process of

5 subjectification through police intervention (on control and subjectification, see Rose, 2000, pp. 330-331) (F).

\section{The Eviction and Shutting Down of the Grassroots Organization Center}

9 At the time, the building hosted a grassroots organization ("Bouge qui Bouge"), which was headed by the brother of Mohammed Berrichi, the

11 second youth killed in the May events. The center had become the effective nerve center of the political mobilization: it was the place where

13 journalists, political parties, and other grassroots organizations were invited to meet, where equipment was kept, where decisions were made,

15 information brochures were written, etc. A court bailiff let the organization know that the center would be closed and restituted to the Public

17 Housing Society (headed by the conservative representative of a neighboring city) who some years ago had agreed to lend the center to the

19 organization free of charge. According to the bailiff, the deal had been broken following signs of "behavior which is incompatible with the social

21 purpose announced by the organization, and specified in the contract establishing the free lease." In a decision taken on July 18th, the court of

23 appeals ruled that the center should be given back to the grassroots organization. The keys were to be handed back to the organization on

25 July 29 th. On July 27 th, however, the center went up in flames, and was entirely destroyed.

27 What is the social background of the protesters? Low education levels, geographic alienation from city-centers, limited options in terms of vital

29 resources (housing and employment): the scarcity and precariousness of resources available to them stand in stark contrast with the stability and

31 perpetuation over decades of the local conservative political elites, who not only occupy all elected official positions (national assembly, senate, city

33 councils), but also (and, in fact, consequently) disproportionately head local administrations, including the one in charge of social housing. One of the

35 consequences of this asymmetry in the distribution of public resources is the use of police forces by local elites to try to control the expression of public

37 opinion. The signs of undesirable "behavior" referred to by the local court, the eviction demanded by the social housing administration, and the final

39 restitution of the center are all based on a political economy of suspicion. Clearly, this economy of suspicion leads to the strong polarization of 
1 collective identities - to the formation of a "we" which is not, as in the case of Orly, directed against a common enemy, an absent terrorist, but, rather,

3 against a particular State's authority: the police $(\mathrm{G}){ }^{10}$

These features of the local administration make Dammarie-les-Lys, and

5 more specifically the Bas-Moulin building, a place which is in a permanent state of exception $(\mathrm{H})$. Contrary to the implications of the generalization of

7 this concept by Giorgio Agamben's (1998), "permanent state of exception" does not make the area a place with no link to politics, no relationship with

9 political forces: it is not a zone of "bare life," which has become an abandoned "camp." The Bas-Moulin is, however, a zone where the

11 formation of individual (F) and collective $(\mathrm{G})$ identities are determined by an administrative body, the police. Traditionally, such identities would

13 normally form out of politicization processes anchored in the usual social spheres (the workplace - politicization through a labor union; the family -

15 the shaping of opinion; income, or capital - the formation of political preference; the grassroots organization - the expression of local or universal

17 concerns). The local administration uses repressive means (with police forces, but also, as we will see, via judiciary means) to hang over individual

19 lives and collective destinies, where, in Orly, its discretionary power is blocked by the prevalence of socio-technical procedures.

\section{A Perennial and Personal Relationship With the Administration}

Adding to the consecration of the state of exception $(\mathrm{H})$ in the Bas-Moulin,

27 there is a clear personalization of the relationship between police and targeted subjects, which gradually takes on a perennial character (C). One

29 of the central features leading to this intimacy between police and individuals was the criminalization of verbal assaults on police officers and

31 resistance against police officers (art. 433-5 and -6, French Penal Code, $\mathrm{CP})$. On July 6th, a gathering of protesters was to be held in the city center:

33 the aim was to break the invisible walls confining the protest within one excluded area symbolically defined by the GIR intervention, and to bring

35 the issue onto larger public areas. The Mayor, however, allegedly reacting to the "constant climate of tension and insecurity in the town over the past

37 month," decided to prohibit the gathering. Note that violent protests are common in France, but their prohibition is actually very rare (Fillieule \&

39 della Porta, 1998). Here again, the routinization of the state of exception in the area is striking $(\mathrm{H})$. 
1 Charges of Verbal Assault on a Police Officer as a Tool for Political Regulation

3 On July 5th, the day before the gathering was to take place, Abdelkader Berrichi, president of the grassroots organization "Bouge qui Bouge" and

5 brother of the deceased Mohammed, was taken into police custody. He was accused of verbally assaulting police officers during their intervention in the

7 organization center on June 27th. Shortly before he was taken in, Berrichi had been discussing a way to get around the Mayor's prohibition with one

9 of the Prefect's assistants (while, in France, protests may be previously discussed with the Mayor, it is the Prefect who has authority over the police,

11 and thus over public places - sometimes regardless of what the Mayor says see Fillieule \& Jobard, 1998). Negotiations were then taken up by one of

13 Berrichi's friends, ${ }^{11}$ who demanded his release - which the Prefect granted two hours later.

15 In this case, it clearly appears that police forces can use the criminal justice system in order to serve the local political elites, as shown by the time

17 the decision to put Abdelkader Berrichi in custody had been taken. It is also interesting to note that at times, even the central State (locally embodied by

19 the Prefect) must intervene to restore the balance in the political moves made by the various protagonists (in this case to prompt a de-escalation

21 process, see Edelman, 1969). Thus, the process of politicization of a criminal justice system which allows for local officials to use policing tools in their

23 interests and appears as a constant threat over potential protesters can, in rare instances, be blocked by an administrative act, here illustrated by the

25 Prefect's use of exceptional powers to intervene in judiciary matters (freeing a man from custody and a summoning).

29 the Administration

Let us return to the charge of verbal assault against a police officer in itself.

31 On July 1st, Berrichi had used "nique ta mere" ("fuck your mother"), a usual insult in deprived suburban areas, against a police officer. Throughout

33 his life, Berrichi was summoned four or five times for verbal assault, the last having been in Paris Court of Appeal in May 2007 for verbal assault and

35 resistance against police officers of Dammarie's neighboring town. What is striking about the June 27th case, though, is that eight police officers sued

37 for damages: eight policemen claimed to have heard the slur, and considered that they were eligible, in a civil lawsuit, for financial reparation.

39 Usually, this sort of reparation is minimal (about 300 Euros, as stated by Jobard, 2004). However, it is not so much the financial aspect which makes 
1 the verbal assault an administrative tool. When a police officer sues for damages, he or she reverses the nature of offense. Originally defined as an

3 offense against a police officer and, as such, against the State's authority (the assault is said to be "against a public authority's deputy", in the terms

5 of art. 433-5 CP), the assault becomes a mere interpersonal offense, since, beyond the assault alleged against the State, the officer asks the judge to

7 recognize his or her own psychological casualty resulting from the offense as a person, not as a State's deputy anymore. The tendency for police officers

9 to sue for psychological damages has increased since the end of the 1980s (at least in Dammarie-les-Lys; see Jobard, 2004). The end of the 1980s is also

11 when the relationship between police and targeted individuals, or, more accurately, between police and police property, as the young protesters in

13 Dammarie-les-Lys were perceived (B), started to crystallize.

\section{Perrenialization of the Relationship}

17 As mentioned above, the reparation for verbal assault is financial (for prison sentences as an alternative, due, for instance, to a lack of financial

19 resources, see Aubusson de Cavarlay, 1985; Hodgson, 2002). Yet, one of the characteristic features of the target individuals here is their constant

21 inability to pay, due to the social background we previously evoked. Police, who generally know this, rarely take the procedure much further. But

23 judges are through these unended civil proceedings provided with an exceptional tool for making their relationship with target individuals

25 perennial: a disciplinary tool, the civil decision to repair the damage always hangs above the head of a target individual when he or she has to appear

27 before the justice system again, or when the justice department itself seeks to close open cases $(\mathrm{H})$.

29 As we can see, Dammarie-les-Lys is a site of State sovereignty display, which rests on an ancient mode of relationship between the administration

31 and the administered: an inter-individual, immediate, personalized, and asymmetrical relationship, always characterized by an imminent use of

33 violence. ${ }^{12}$ Such display of sovereignty is obviously contrary to the neoliberal governmentality requirements and its three "e"s: efficiency, effec-

35 tiveness, economy. Its legitimization lies in the government itself. This circular governmental rationality supports D. Garland's hypothesis against

37 the governmentality literature, which takes it as axiomatic that government is a problem-solving activity (1997). Dammarie-les-Lys is, indeed, a place

39 manifesting a "wertrational" sovereignty, whose logic is absolutist, not strategic. 


\section{TEMPORAL ARRANGEMENTS AND SPATIAL REGIMES OF SURVEILLANCE}

Two sites, two antagonistic surveillance practices. It is relevant to assess the consequences of their differences. In the one, the international Orly airport, well-defined authorities control the access modalities onto and in a space divided into units and sub-units. The institutions interact with consumers, strangers, with whom they engage for a strictly defined purpose. During the

9 sorting and checking operations, each interaction is unique and immediate in the sense that it does not allow for any perrenialization of the relationship

11 between surveillance agents and individuals under surveillance. It is not recorded, cannot be used in a different temporality, or even reiterated. Each

13 test is a new test - each time an object or a person passes through the unit or sub-unit, the process starts again. The justification for the apparatus, its

15 political rationality, resides in the combination of the need for security, and the need for the traffic of people, luggage, and shipment to be maintained.

17 Given the extremely low chance of actually being in the presence of the enemy, this norm - a pragmatic norm, combining commercial and moral

19 imperatives - is, in fine, the greatest source of constraint but also the best way to assess the efficiency of the apparatus. The apparatus rests on the

21 "iridescence" of the passerby: it does not focus on the intentions, past, or even the being as such of the individuals. Instead, individuals are subject to a

23 series of tests with pre-defined parameters. Every passerby is part of a greater community in that he or she is linked to the surveillance institutions

25 by the invisible presence of a common enemy whose threat must not disrupt the constant mobility within the airport.

27 From a surveillance standpoint, Dammarie-les-Lys is almost in perfect opposition to the Orly situation. The overlay of institutions is such that they

29 seem to become one, almost in a paramilitary fashion. The intervention targets are familiar targets, and one of the consequences of intervention is

31 the reinforcement of the sorting of the non-familiar faces, and the recognition of those who are already familiar. The relationship is based

33 on a repetition of interactions, which are recorded in several types of memories (individual or collective, codified or otherwise), which can be

35 reinvested in future interactions. The consequences of the surveillance procedure are the subjectification of the surveillance targets and the

37 formation of a community defined by the antagonism felt toward the surveillance institutions. A guardianship relationship follows from it.

39 Indeed, the practice of surveillance in Dammarie-les-Lys creates a space where individuals depend on surveillance institutions, with whom they have 
1 a relationship, which is marked in time and highly personal. Throughout the repetition of the interactions, surveillance is reinforced by legal trails

3 and the mutual identification between policemen and targeted individuals that follow, so that the state of dependence is coupled with a form of

5 subjectification, the shaping of an individual identity, a self, and of a collective identity, a we (Table 2).

7 What does the comparison between these two entirely different cases tell us about the surveillance/governance couple? First, that it is necessary to

9 keep eventfulness in mind when thinking of governmentality. Both sites also have a peculiar relationship with time. The study focused on the surveillance

11 apparatus of Orly airport on a normal day. The event, or, rather, the

Table 2. Synoptic Table of the Findings of the Comparison.

Variables

Test

Guardianship

Descriptive Variables

19

(A) Institutional

arrangement

(A1) Division into

(A2) Overlay

sectors

(B1) Strangers

(customers)

21

(C)

surveillance

(D1) Uniqueness

(B2) Inhabitants

(locals)

Type of interaction

(E1) No recording

(D2) Iteration

23 (D)

Absence or presence of

(E2) Recording record

(E)

$$
\text { Sources of }
$$
legitimacy

(G1) Mobility

(G2) Residence

Analytical Variables

29

(F) Effects of surveillance on

(C1) Objectification

(C2)

Subjectification the individual status of its targets

(G)

Effects of surveillance on the collective status of its targets

(H)
Type of intervention

(H2)

$$
\begin{aligned}
& \text { Two } \\
& \text { antagonistic } \\
& \text { "we"s }
\end{aligned}
$$

(F2) 
1 emergency, is in virtual reality - and the normalized, standardized, uniform feature of the various security processes are specifically designed to keep it

3 that way. On the other hand, the study of the Dammarie-les-Lys apparatus was undertaken in the heat of a specific moment, or event (a political

5 mobilization following two deaths). This dimension, the unpredictable feature of an every-day life which is always on the verge of a crisis, is

7 neglected by the bulk of the literature on governmentality. To acknowledge the relevance of the event is to understand how the governmentality agencies

9 both act on the spur of the moment and organize the future while at the same time tightening their grip on society. The observation of the

11 surveillance apparatus during a disruptive event in Dammarie-les-Lys shows how surveillance becomes an element of a form of governance based on the

13 settlement of an extremely unique time: the time of permanent exception.

A close look at history, at the actual interactions between governance

15 agencies and their targets (the citizens, the passengers, the customers ...) also helps understand that, despite the political rationalities in place in

17 advanced liberal democracies (Rose \& Miller, 1992, p. 180; Rose, 2000, p. 323) and the subjectification born out of a "new penology" (Simon \&

19 Feeley, 2003), some places still bear the marks of ancient forms of governance: personalization and perrenialization of the relationships

21 between agents of governance and the governed, politicization of relationships, permanent imminence of physical contact. Other sites, such as Orly

23 airport, are also places where State agencies are present, but State control does not rely on the display of power or on the threat of violence. Rather, it

25 relies on the introduction of control programs in a machine-like apparatus: control becomes the product of a machine of machines.

27 In his lectures "Security, territory, population", Michel Foucault had identified this question of eventfulness and of unpredictability. But he had

29 also identified a second question, closely related to the first: the question of space and the necessity of dividing it, creating grid patterns within it - in

31 other words, the necessity of rationalizing space (Foucault, 1978). As different from each other as they may be, both sites under observation show

33 different mechanisms of political rationality in Foucault's sense, that is, manners of "conducting conducts" (Foucault, 1981; Gautier, 1996) closely

35 linked to space-penetration. In both cases, control means a total knowledge and coverage of the geographic space, and the adjustment of every 37 operation to specific spatial constraints. But the way the space is apprehended in each case is entirely different. At the Orly airport, the

39 space is seen as purely transitory. Hence, the division of space into sub-units can be understood as the provision of a set of directions, which allow a 
1 better understanding of the space without territorializing it as such. These sub-units are not territories, in that they do not have inhabitants, and that

3 no one has a permanent relationship with them: in fact, the zones are precisely designed for people to pass through them. The resulting

5 organization of the space, almost geometrical, is designed to fit a principle of regulation, which cannot be ignored without affecting the sole purpose of

7 the airport: the preservation of the continuity of the flow of transit and the reduction of the likeliness of friction. An entirely different story in

9 Dammarie-les-Lys. In opposition to the Euclidean regime of Orly airport, the Bas-Moulin project is under a chôra regime (Berque, 2000, pp. 20-25):

11 the site cannot be separated from its inhabitants, nor can inhabitants be separated from their place of residency: they "wear" the site, just like site

13 "sticks" to them. Here, the territorialization is at its strongest.

The examples we have used are sufficient to reveal the importance of

19 ensuring that analyses of surveillance and of its governance map the sites under surveillance to better identify what singles them out, take the various

21 modes of access across zones into account, and identify the political rationality which emerges from the interlacing of spaces - or on the contrary,

23 from their strict separation. Michel Foucault called this necessity "heterotopology" (Foucault, 2001). But the cartography is also a marked in time: as

25 underlined by Michel Foucault, "more often than not, heterotopies are linked to divisions of time, that is to say that they open up onto what, by

27 pure symmetry, we could call, 'heterochronies."' If the check and guardianship models put forward a contrast between the time of repetition and the

29 time of the event, it is because all forms of governance of surveillance, in fact, lead to a specific time arrangement. If we keep this in mind during our

31 analyses, we place ourselves in a better position to contribute to the literature on criminology which tends to focus on various forms of "government at a

33 distance" on the one hand, and on withdrawn places of incarceration on the other - and as a result, to neglect the great diversity of modes of control and

35 surveillance, and the way they produce individual and collective identities.

\section{UNCITED REFERENCES}

Collins (1990); Goldberg (1991); Pinch (1993). 


\section{NOTES}

3 1. Right up until his final lectures, M. Foucault paid particular attention to the spatial anchorage of discipline and security devices. See, in particular, his treatment of urban space in his lectures at the Collège de France in 1977-1978 (Foucault, 2004).

2. In order to make our text easier to follow, our empirical descriptions will include uppercase letters corresponding to the variables where appropriate.

7 3. To quote James Beniger (1986), the historical feature of terrorism prevention in airports can be interpreted as a sequence of alternations between situations of control

9 crisis and control revolution - the latter understood as what facilitates the transition from a world which has become uncontrollable because of transformations in the nature of the threat it could face to a world once again under control, thanks to the

11 establishment of an apparatus able to contain and apprehend new risks within a process of rationalization and normalization. The latest crisis to date was triggered by

13 the realization of the existence of liquid explosives concealable in bottles and flasks.

4. Here, one may recall the widely broadcast images after the September 11 th attacks showing the hijackers going through security checks at the Portland airport.

15 The outrage produced by the images comes from the double lack of efficiency they disclose: not only did passenger checks not allow security to catch the terrorists, but

17 the images revealing the first breakdown in efficiency come from no other than surveillance cameras themselves.

5. The most important border is that between the "public zone" and the "restricted zone." Its purpose is to ensure that all necessary functions for take off are concentrated within the restricted zone, and that all others are excluded. The restricted zone includes the post-transborder filter area inside the terminal as well as the traffic area, the control tower, and certain technical rooms outside the terminal.

23 Within the restricted zone, there is a subdivision separating "security sectors" from "functional sectors." Given their proximity to the aircraft, security sectors have the strictest access policies.

256 . For a description of the relationship between the consumer and the airport, see Rosler (1994).

27 7. To take a concrete example: at a security checkpoint, an agent signals the presence of a hand-grenade in a piece of hand luggage. We know nothing of the

29 passenger, nor whether he has ill intentions or not. After all, the grenade may be a collector's item (which it turned out to be). Nonetheless, the passenger is not authorized to go through - not because he is considered a terrorist, but because he

31 does not satisfy the criteria of "cleanness." On the other hand, all the passenger had to go through to give his hand-grenade to the security agent - and this would have

33 been the case even if he had been a terrorist.

8. A more detailed account of these events was published in Jobard (2004). Numerous documents, archives, and pictures are also available on: http:// vacarme.eu.org/rubrique102.html

9. In the narrow sense of Miller and Rose (1992, p. 175): "the moral justification of

37 power." Further on, we will be using this term in the larger sense promoted by Foucault.

10. In a similar vein, see Escobar (1999).

39 11. The transcripts of the interaction can be found at: http://vacarme.eu.org/ article $377 . \mathrm{html}$ 
12. The sovereignty we are referring to is the one described by Foucault (1977), such as the ancient mode of power display which preceded the emergence of discipline.

\section{REFERENCES}

Adey, P. (2003). Secured and sorted mobilities: Examples from the airport. Surveillance and Society, 1(4), 500-519.

Agamben, G. (1998). Homo sacer: Sovereign power and bare life. Stanford, CA: Stanford University Press.

11 Akrich, M. (1992). The de-scription of technical objects. In: W. E. Bijker \& J. Law (Eds), Shaping technology, building society (pp. 205-225). Cambridge, MA: MIT Press.

Beniger, J. (1986). The control revolution: Technological and economic origins of information society. Cambridge, MA: Harvard University Press.

Berque, A. (2000). Ecoumène. Introduction à l'étude des milieux humains. Paris: Belin.

Campbell, B. (1983). Goliath. Britain's dangerous places. London: Methuen.

Collins, H. M. (1990). Artificial experts: Social knowledge and intelligent machines. Cambridge, MA: MIT Press.

Deleuze, G. (1988). Foucault. Minneapolis, MN: University of Minnesota Press.

Edelman, M. (1969). Escalation and ritualization of political conflict. American Behavioral Scientist, 13(2), 231-246.

Escobar, J. E. (1999). Race, police, and the making of a political identity: Mexican Americans and the Los Angeles police department, 1900-1945. Berkeley, CA: University of California Press.

Fijnaut, C., \& Marx, G. T. (1995). Undercover. Police surveillance in comparative perspective. The Hague: Kluwer International.

Fillieule, O., \& Jobard, F. (1998). The Maintenance of order in France. Towards a model of protest policing. In: D. della Porta \& H. Reiter (Eds), The policing of mass demonstrations in contemporary democracies (pp. 70-90). Minneapolis, MN: University of Minnesota Press.

Fillieule, O., \& della Porta, D. (1998). Policing protest in France and Italy. From intimidation to cooperation? In: S. Tarrow \& D. Meyer (Eds), The social movement society. Contentious politics for a new century (pp. 111-130). Boulder, CO: Rowland and Littlefield.

31 Foucault, M. (1977). Discipline and punish. The birth of the prison. New York: Pantheon.

Foucault, M. (1981). Omnes et singulatim. Towards a criticism of political reason. In: S. McMurrin (Ed.), The Tanner lectures on human values (vol. 2, pp. 223-254). Salt Lake City, UT: The University of Utah Press.

Foucault, M. (1988). The political technology of individuals. In: P. H. Hutton, H. Gutman \& L. H. Martin (Eds), Technologies of the self. A seminar with Michel Foucault (pp. 145-162). Amherst, MA: The University of Massachusetts.

Foucault, M. (2001). Des espaces autres. In: M. Foucault (Ed.), Dits et Ecrits (Vol. 2, pp. 1571-1581). Paris: Gallimard.

Foucault, M. (2004). Sécurité, territoire, population. Cours au Collège de France (1977-1978). Paris: Gallimard/Le Seuil. 
1 Gandy, O. H. (1993). The panoptic sort: A political economy of personal information. Boulder, CO: Westview.

3 Garland, D. (1997). "Governmentality" and the problem of crime. Foucault, criminology, sociology. Theoretical Criminology, 1(2), 173-214.

Gautier, C. (1996). À propos du gouvernement des conduites chez Foucault. In: CURAPP (Ed.), La gouvernabilité (pp. 19-33). Paris: Presses universitaires de France.

Goffman, E. (1971). Relations in public: Microstudies of the public order. New York, NY: Basic Books.

Goldberg, J. E. (1991). Understanding the dimensions of terrorism. Perspectives on Political Science, 20(2), 78-88.

Hodgson, J. (2002). Hierarchy, bureaucracy and ideology in French criminal justice: Some empirical observations. Journal of Law and Society, 29(2), 227-257.

11 Jobard, F. (2004). Der ort der politik. Politische mobilisierung zwischen aufstandsversuchung und staatsgewalt in einer pariser vorstadt. Berliner Journal für Soziologie, 2004/3, 319-338.

Jobard, F. (2007). Urban riots in France, 2005. Data-based interpretations. Submitted to Compass Blackwell online.

15 Kraska, P. B., \& Kappeller, V. E. (1997). Militarizing the American police: The rise and normalization of paramilitary units. Social Problems, 44(1), 1-18.

17 Latour, B. (1987). Science in action: How to follow scientists and engineers through society. Cambridge, MA: Harvard University Press.

Latour, B., \& Hermant, E. (1998). Paris ville invisible. Paris: Les empêcheurs de penser en rond.

Linhardt, D. (2000). Demokratische Maschinen? Die Vorrichtung zur Terrorismusbekämpfung in einem französischen Großflughafen. Kriminologisches Journal, 32(2), 82-107.

21 Linhardt, D. (2001). L'économie du soupçon. Une contribution pragmatique à la sociologie de la menace. Genèses, 44, 76-98.

Linhardt, D. (2006). Guerrilla diffusa. Clandestinité, soupçon et provocation dans le conflit entre organisations révolutionnaires subversives et l'État ouest-allemand (années 1970). Politix, 19(74), 75-102.

Lyon, D. (1994). The electronic eye: The rise of surveillance society. Minneapolis, MN: University of Minnesota Press.

27 Lyon, D. (2003). Airports as data filters: Converging surveillance systems after September 11th. Information, Communication and Ethics in Society, 1(1), 13-20.

Merari, A. (1998). Attacks on civil aviation: Trends and lessons. In: P. Wilkinson \& B. M. Jenkins (Eds), Aviation terrorism and security (pp. 9-27). London: Frank Cass.

Norman, D. (1991). Cognitive artifacts. In: J. M. Caroll (Ed.), Designing interaction:

Psychology at the human-computer interface (pp. 17-38). New York: Cambridge University Press.

Pinch, T. (1993). “Testing - one, two, three ... testing!” toward a sociology of testing. Science, Technology, and Human Values, 18(1), 25-41.

Rose, N. (2000). Government and control. British Journal of Criminology, 40(2), 321-339.

Rose, N., \& Miller, P. (1992). Political power beyond the State. Problematics of government. British Journal of Sociology, 43(2), 173-205.

37 Rosler, M. (1994). In the place of the public: Observations of a frequent flyer. Assemblages, $25,44-79$.

Roy, O. (2005). The nature of the French riots. SSRC. 18th November. Available online at: http://riotsfrance.ssrc.org/Roy/ 
1 Salter, M. B. (2007). Governmentalities of an airport: Heterotopia and confession. International Political Sociology, 1(1), 49-66.

3 Schütz, A. (1971). Das problem der relevanz. Frankfurt/M.: Suhrkamp.

Sharpe, S. (2000). Search and surveillance. The movement from evidence to information. Aldershot: Ashgate.

5 Simon, J., \& Feeley, M. (2003). The form and limits of the new penology. In: T. Blumberg \& S. Cohen (Eds), Punishment and social control (Enlarged 2nd ed., pp. 75-116). New 7 York, NY: Aldine de Gruyter.

Singel, B. (2003). JetBlue shared passenger data. Wired News. 18th September. Available online at: http://www.wired.com/news/privacy/0,1848,60489,00.html

Tilly, Ch. (2003). The politics of collective violence. Cambridge, MA: Cambridge University Press.

11 Urry, J. (2000). Sociology beyond societies: Mobilities for the 21st century. London: Routledge. Waddington, D., Jones, K., \& Critcher, C. (1989). Flashpoints. Studies in public disorders.

\section{London: Routledge.}

Wallis, R. (1998). The role of international aviation organizations in enhancing security. In: P. Wilkinson \& B. M. Jenkins (Eds), Aviation terrorism and security (pp. 82-100). London: Frank Cass.

Walzer, M. (1977). Just and unjust wars: A moral argument with historical illustrations. New York: Basic Books. 
AUTHOR QUERY FORM

\begin{tabular}{|l|l|l|}
\hline 3 & Book: SLCD-V010 & $\begin{array}{l}\text { Please eail or fax your responses and any corrections to: } \\
\text { Eail: } \\
\text { Fax: }\end{array}$ \\
\hline
\end{tabular} Dear Author,

7 During the preparation of your manuscript for typesetting, some questions may have arisen. These are listed below. Please check your typeset proof carefully and mark any corrections in

9 the margin of the proof or compile them as a separate list*.

11 Disk use

1 Sometimes we are unable to process the electronic file of your article and/or artwork. If this is the case, we have proceeded by:

$13 \square$ Scanning (parts of) your article $\square$ Rekeying (parts of) your article

$\square$ Scanning the artwork

\section{Bibliography}

If discrepancies were noted between the literature list and the text references, the following may

17 apply:

$19 \square$ The references listed below were noted in the text but appear to be missi

$\square$ Uncited references: This section comprises references that occur in the reference list but not

21 in the body of the text. Please position each reference in the text or delete it. Any reference not dealt with will be retained inthis section

23 Queries and/or remarks

\begin{tabular}{|l|l|l|}
\hline $\begin{array}{l}\text { Location in } \\
\text { Article }\end{array}$ & Query / remark & Response \\
\hline AU:1 & $\begin{array}{l}\text { Please confirm whether the year } \\
\text { of publication is 1988 or 1986 in } \\
\text { Deleuze (1988). }\end{array}$ & \\
\hline AU:2 & $\begin{array}{l}\text { The following references are not } \\
\text { listed in the reference list. Please } \\
\text { provide. Miller and Rose (1992), } \\
\text { Wood (2003), Urry (2002), } \\
\text { Pinch, (2003), (Foucault, 1975), } \\
\text { Aubusson de Cavarlay, 1985, } \\
\text { Crenshaw, 1988, (Collins, 1992), } \\
\text { (Foucault, 1978), Miller \& Rose } \\
\text { (1992, 175). }\end{array}$ \\
\hline AU:3 & $\begin{array}{l}\text { Please confirm the citations for } \\
\text { Tables 1 and 2. }\end{array}$ \\
\hline
\end{tabular}




\begin{tabular}{l|l|l|l|}
1 & AU:4 & $\begin{array}{l}\text { Please confirm whether the year } \\
\text { of publication is } 2000 \text { or } 2002 \text { in } \\
\text { Urry (2000). }\end{array}$ \\
\cline { 2 - 4 } 5 & AU:5 & $\begin{array}{l}\text { Please check if the changes made } \\
\text { to the sentence is correct. }\end{array}$ & \\
\cline { 2 - 4 } & &
\end{tabular}

7

13

15

17

19

21

23

25

27

29

31

33

35

37

39 